論 文・Paper

\title{
塩化ジルコニウム $(\mathrm{IV})$ からの窒化ジルコニウム 粉末の合成
}

\author{
神山美英・荒川敏彦・森 忠芸・飯田武揚・ 三田村 孝 \\ (埼玉大学 工学部 応用化学科)
}

\begin{abstract}
八ロゲン化物法により，室素ガス流通 $(100 \sim 200 \mathrm{ml} / \mathrm{min})$ 下, $200^{\circ} \sim 1050^{\circ} \mathrm{C}$ の温度範囲で $\mathrm{ZrCl}_{4}$ からの $\mathrm{ZrN}$ 粉末の合成を試みた。特に, 還元剂の影響に着目し, $\mathrm{Al}, \mathrm{Mg}$ 及び $\mathrm{Zn}$ 粉末の 3 種類について比較検討した。これら還元剂の中では $\mathrm{Al}$ が最も有効で, $800^{\circ} \mathrm{C}$ 以上で $\mathrm{ZrN}$ が生成し た。しかし, 窒化の進行が遅い場合は合金相の $\mathrm{Al}_{3} \mathrm{Zr}$ が生成した。この窒化反応の見掛けの活性化 エネルギーは約 $28.7 \mathrm{kcal} / \mathrm{mol}\left(850^{\circ} \sim 1050^{\circ} \mathrm{C}\right)$ であった. $1050^{\circ} \mathrm{C}, 1 \mathrm{~h}$ 反応で得られた生成物は 微粉末 $(0.1 \sim 0.3 \mu \mathrm{m})$ で, 単相の $\mathrm{ZrN}$ であり, 格子定数 $a$ は $4.575 \AA$, 結晶子径は $259 \AA$ 凡゙あった. しかし, $\mathrm{ZrCl}_{4}$ の昇華損失により $\mathrm{Al}$ の残留が認められた. 残留 $\mathrm{Al}$ は $1 \mathrm{~N}$ 水酸化ナトリウムでほぼ 除去できた。一方, $\mathrm{Mg}$ では窒化反応の進行が遅く, $\mathrm{ZrN}$ は粗大粒子となった。また， $\mathrm{Zn}$ では ZrN を合成することはできなかった。

(1983 年 6 月 20 日受付)
\end{abstract}

\section{Preparation of Zirconium Nitride Powder from Zirconium Chloride (IV)}

\author{
Yoshihide KAMIYAMA, Toshihiko ARAKAWA, Tadaaki MORI, \\ Takeaki IIDA and Takashi MITAMURA \\ Department of Applied Chemistry, Faculty of Engineering, \\ Saitama University \\ 255, Shimo-ohkubo, Urawa-shi 338
}

\begin{abstract}
$\mathrm{ZrN}$ powder was prepared from $\mathrm{ZrCl}_{4}$ by the halogenide process in a nitrogen gas flow (100-200 $\mathrm{ml} / \mathrm{min}$ ) at the temperatures from $200^{\circ} \mathrm{C}$ to $1050^{\circ} \mathrm{C}$. Particularly, the influences of reducing agents, $\mathrm{Al}, \mathrm{Mg}$ and $\mathrm{Zn}$ powder were examined. The $\mathrm{Al}$ powder was found to be the most effective reducing agent among them, and $\mathrm{ZrN}$ powder was odtained above $800^{\circ} \mathrm{C}$. In the slow nitriding reaction, however, an alloy phase of $\mathrm{Al}_{3} \mathrm{Zr}$ was formed. The apparent activation energy of the reaction was $28.7 \mathrm{kcal} / \mathrm{mol}\left(850^{\circ}-1050^{\circ} \mathrm{C}\right)$. The fine powder $(0.1-0.3 \mu \mathrm{m})$ of onephase $\mathrm{ZrN}$ was obtained at $1050^{\circ} \mathrm{C}$ after $1 \mathrm{~h}$. The lattice parameter $a$ and the crystallite size of $\mathrm{ZrN}$ were $4.575 \AA$ and $259 \AA$, respectively. However, because of the sublimation loss of $\mathrm{ZrCl}_{4}$, the residual $\mathrm{Al}$ was found in the products. This $\mathrm{Al}$ was removed almost completely by washing with $1 \mathrm{~N} \mathrm{NaOH}$. On the other hand, in the system $\mathrm{ZrCl}_{4}-\mathrm{Mg}-\mathrm{N}_{2}$, the process of the nitriding reaction was slow, and only coarse particles of $\mathrm{ZrN}$ were obtained. In the system $\mathrm{ZrCl}_{4}-\mathrm{Zn}_{\mathrm{n}} \mathrm{N}_{2}$, $\mathrm{ZrN}$ was not prepared.

[Received June 20, 1983]
\end{abstract}

Key-words : Preparation, $\mathrm{ZrN}$ powder, $\mathrm{ZrCl}_{4}$, Halogenide process, Nitrogen, Reducing agent, System $\mathrm{ZrCl}_{4}-\mathrm{Al}-\mathrm{N}_{2}$, System $\mathrm{ZrCl}_{4}-\mathrm{Mg}-\mathrm{N}_{2}$

\section{1. 緒言}

窒化ジルコニウム（以下 $\mathrm{ZrN}$ とする）は, 高融点 $\left(2982^{\circ} \mathrm{C}\right.$ ), 高硬度 (微小硬度 ; $1500 \mathrm{~kg} / \mathrm{mm}^{2}$ ) を有し, 熱的, 電気的にも興味深い性質を持つ化合物である ${ }^{11}$. 出発原料に塩化ジルコニウム ( IV) (以下 $\mathrm{ZrCl}_{4}$ とする) を用い, 気相からの $\mathrm{ZrN}$ の析出については, $\mathrm{ZrCl}_{4}$ $\mathrm{H}_{2}-\mathrm{N}_{2}$ 系で Agte らのタングステン線上での析出 ${ }^{2)}$,
Campbell らの黒鉛上への被覆 ${ }^{31}$ に関する報告, また, 黒鉛基板上でのホイスカ一の成長について高橋ら ${ }^{41}$, 及 び，三好ら ${ }^{5)}$ の報告がある。このほか，Juzaらは $\mathrm{ZrCl}_{4}$ のアンモノリシスにより金属状の $\mathrm{ZrN}$ を得ている6 ${ }^{6}$.

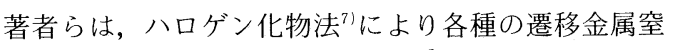
化物 $\left(\mathrm{UN}^{81}, \mathrm{TiN}^{91,10)}, \mathrm{CrN}^{11 !}\right)$ 粉末の合成について報 告してきた。本研究では, $\mathrm{ZrCl}_{4}$ からの $\mathrm{ZrN}$ の合成を 


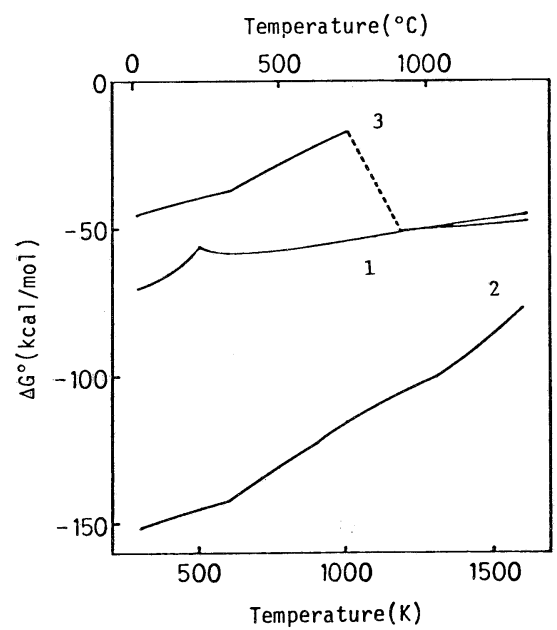

Fig. 1. Free energy changes of formation for the system of $\mathrm{ZrCl}_{4}-\mathrm{Al}-\mathrm{N}_{2}$.

Reaction :

(1) $\mathrm{ZrCl}_{4}+4 / 3 \mathrm{Al}+1 / 2 \mathrm{~N}_{2} \rightarrow \mathrm{ZrN}+4 / 3 \mathrm{AlCl}_{3}$

(2) $\mathrm{ZrCl}_{4}+2 \mathrm{Mg}+1 / 2 \mathrm{~N}_{2} \rightarrow \mathrm{ZrN}+2 \mathrm{MgCl}_{2}$

(3) $\mathrm{ZrCl}_{4}+2 \mathrm{Zn}+1 / 2 \mathrm{~N}_{2} \rightarrow \mathrm{ZrN}+2 \mathrm{ZnCl}_{2}$

試み，その生成条件と反応機構を検討した．この際，還 元剂にアルミニウム, マグネシウム及び亜鉛（以下 $\mathrm{Al}$, $\mathrm{Mg}$ 及び $\mathrm{Zn}$ とする) 粉末を用いて比較した。図 1 に $300 \sim 1600 \mathrm{~K}$ の温度範囲で各還元金属存在下での $\mathrm{ZrN}$ 生成反応についての生成自由エネルギー変化 $\Delta G^{0}$ を示 $す^{12), 13)}$.これによると，いずれの系でも $\mathrm{ZrN}$ の生成が 自発的に進むことが可能であるが, 還元力は $\mathrm{Mg}$ が最 も強く，また， Zn の還元力は沸点 $\left(930^{\circ} \mathrm{C}\right)$ 以上で発 揮されることが示唆される. $\mathrm{Al}$ の還元力は両者の中間 に位置するようである.

\section{2. 実験方法}

市販の $\mathrm{ZrCl}_{4}$ (Alfa Chemical 製, 純度 $98 \%$ ) を昇華 精製したものと還元金属粉末（福田金属箔粉工業製， $\mathrm{Al}$ ：スタンプ法，純度 $99.9 \%, \mathrm{Mg}$ : 粉砕法, 純度 $99 \%$ 以上，Zn : 噴霧法，純度 $99.8 \%$ ）を用い，いずれ も粒度を 200 メッシュ以下にそろえ，十分に窒素ガス置 換したグローブボックス内で混合し，出発試料とした. 試料混合比は図 1 に示した反応に従い, モル比で $\mathrm{ZrCl}_{4}$ $: \mathrm{Al}=3: 4$ 及び $3: 3.2, \mathrm{ZrCl}_{4}: \mathrm{Mg}=1: 2, \mathrm{ZrCl}_{4}$ : $\mathrm{Zn}=1: 2$ とした.

図 2 に合成装置図の概略を示す。合成方法は，グロー ブボックス内で出発試料約 $0.5 \mathrm{~g}$ を反応ボート ( $\mathrm{Al}$ あ るいは Zn を含む試料では石英製， $10 \times 13 \times 80 \mathrm{~mm}$ 厚さ $1 \mathrm{~mm}, \mathrm{Mg}$ を含む試料では黒鉛製, $11 \times 13 \times 65 \mathrm{~mm}$ 厚 さ $2 \mathrm{~mm})$ にとり, 重量減少率を測定する場合は, ボー トの重量をあらかじめ計り，ボートごと試料を精ひょう して初重量とした。これを透明石英製反応管（内径 30

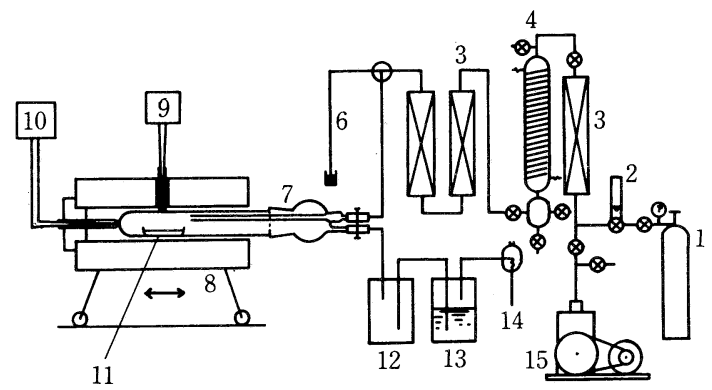

Fig. 2. Schematic diagram of reaction apparatus for preparation of $\mathrm{ZrN}$.

(1) : Cylinder $\left(\mathrm{N}_{2}\right.$ or Ar), ( 2 ): Flowmeter, ( 3 ): $\mathrm{CaCl}_{2}$ tube, (4): Activated $\mathrm{Cu},(5)$ : Zeolite tube, (6) : Hg Manometer, ( 7 ) : Reaction tube, ( 8 ): Electric furnace, ( 9 ): Thermometer, (10): Temp. controller, (11): Sample and reaction boat, (12): Receiver, (13): Scrubbing bottle, (14): Water-jet pump, (15): Vacuum pump

$\mathrm{mm} \phi$, 長さ $450 \mathrm{~mm})$ 内に装てんし, 合成装置に接続した. 反応系内の排気及び精製窒素ガス置換を数回繰り返した のち常圧で窒素ガスを流通させた。窒素ガスの精製は， 脱酸素用の活性化銅管 $\left(160^{\circ} \mathrm{C}\right.$ に加熱), 乾燥用の塩化 カルシウム管及びゼオライト管を用い，ガス流量は 100 〜 $200 \mathrm{ml} / \mathrm{mim}$ とした.この状態で所定の温度に昇温し ておいた電気炉を移動させ反応を開始し，所定時間後電 気炉を戻してから反応管を室温まで水で急冷して反応を 終了した. 反応後の試料重量はボートごと生成物をひょ う量して求めた。

得られた生成物については, 粉末法 X 線回折試験 (理 学電機製 DS 型 X 線回折装置) による同定, 定量, 格 子定数及び結晶子径の測定, 走查型電子顕微境 (SEM) (島津製作所製, EMX-SM ) による表面観察, 比表 面積の測定等を行った。 X 線回折による定量等は, $\mathrm{ZrCl}_{4}-\mathrm{Al}-\mathrm{N}_{2}$ 系では $\mathrm{Si}(99.9 \%)$ を $\mathrm{ZrCl}_{4}-\mathrm{Mg}-\mathrm{N}_{2}$ 系で は $\mathrm{Al}(99.9 \%)$ を用いた内部標準法により行い，生成 $\mathrm{ZrN}$ の結晶子径は Scherrer の式 ${ }^{14)}$ を用いて計算した. また，比表面積は，窒素ガス吸着量を測定し，BET（一 点法 $)^{15)}$ により算出した.

\section{3. 実験結果及び考察}

\section{$3.1 \mathrm{ZrN}$ の合成に及ぼす Al の影響}

従来, 還元金属は主として $\mathrm{Al}$ 粉末が用いられてお $り^{8) \sim 11), 16) ~ 18)}$ ，長時間保存しても比較的酸化が進まず, 安全性も高いなよ゙の利点がある. また, 副生物の塩化ア ルミニウム（III）（以下 $\mathrm{AlCl}_{3}$ とする）が比較的低温 $\left(182.7^{\circ} \mathrm{C}\right)$ で昇華するため生成物から容易に除去され る.

図 3 に, $\mathrm{ZrCl}_{4}-\mathrm{Al}-\mathrm{N}_{2}$ 系, $1 \mathrm{~h}$ 反応の生成物を $\mathrm{X}$ 線回 折試験で定量した結果を示す.反応温度は $200^{\circ} \sim$ 


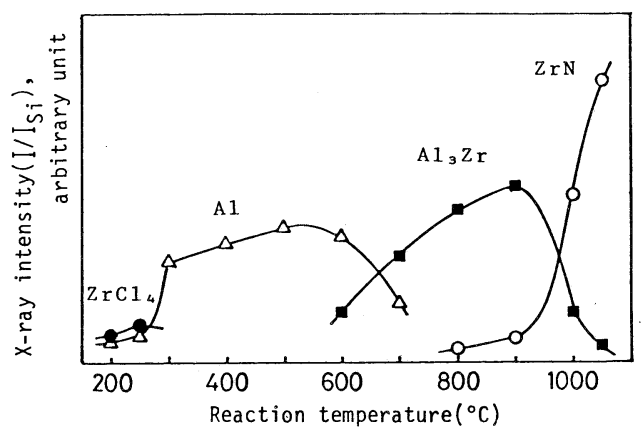

Fig. 3. Changes in relative intensity of X-ray diffraction lines for the products obtained by heating the powder mixture of $\mathrm{ZrCl}_{4}$ and $\mathrm{Al}(3: 3.2$, molar ratio) in $\mathrm{N}_{2}$.

Holding time $: 1 \mathrm{~h}$

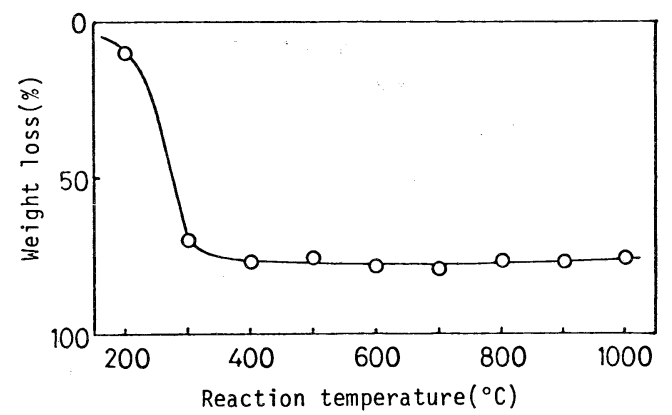

Fig.4. Relationship between weight loss and reaction temperature in the reaction of the system of $\mathrm{ZrCl}_{4}-\mathrm{Al}-\mathrm{N}_{2}\left(\mathrm{ZrCl}_{4}: \mathrm{Al}=3: 4\right.$, molar ratio $)$.

Holding time $: 1 \mathrm{~h}$

$1050^{\circ} \mathrm{C}$ の範囲である.ここでは, 出発試料中の $\mathrm{Al}$ 混合 比は量論比であるが， $80 \%$ にしても同様の結果であっ た。

反応中, 副生した $\mathrm{AlCl}_{3}$ と一部昇華した $\mathrm{ZrCl}_{4}$ は白煙 となり反応管の冷温部に付着するが, $300^{\circ} \mathrm{C}$ 以下ではわ ずかであった。ボート中の生成物には, $300^{\circ} \mathrm{C}$ 付近まで は $\mathrm{ZrCl}_{4}$ が存在するが $400^{\circ} \mathrm{C}$ 以上では見られなかった. しかし, $300^{\circ} \mathrm{C}$ 付近の反応では, 塩化ジルコニウム (III) （以下 $\mathrm{ZrCl}_{3}$ とする）が見られることもあり，反応管の 付着物中に $\mathrm{AlCl}_{3}$ の存在が確認されたことから低温でも 還元反応が起きていることが分る： $500^{\circ} \mathrm{C}$ までは $\mathrm{ZrCl}_{4}$

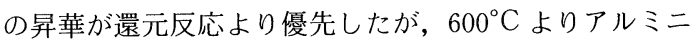
ウム・ジルコニウム合金 $\left(\mathrm{Al}_{3} \mathrm{Zr}\right)$ 相が生成し, $700^{\circ} \mathrm{C}$ で 主生成物となった. 金属 $\mathrm{Zr}$ の回折線が見られなかった が, $800^{\circ} \mathrm{C}$ 以上で $\mathrm{ZrN}$ が生成し, $1050^{\circ} \mathrm{C}$ ではほぼ $\mathrm{ZrN}$ 単相となった.

次に, $\mathrm{ZrCl}_{4}-\mathrm{Al}-\mathrm{N}_{2}$ 系 $1 \mathrm{~h}$ 反応における試料の重量減 少率変化を図 4 に示す. 試料混合比が $\mathrm{ZrCl}_{4}: \mathrm{Al}=3: 4$ のとき, 反応が完結した場合の重量減少率は $60.9 \%$ (理 論值）になる. 図から分かるように $300^{\circ} \mathrm{C}$ の反応で,

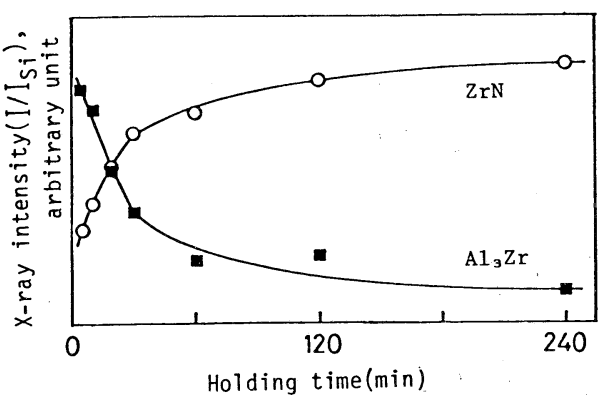

Fig. 5. Changes in relative intensity of X-ray diffraction lines for the products obtained by heating the powder mixture of $\mathrm{ZrCl}_{4}$ and $\mathrm{Al}$ (3:3.2, molar ratio) in $\mathrm{N}_{2}$.

Reaction temperature : $1000^{\circ} \mathrm{C}$

既に $69.9 \%$ となり理論值を上回った。これは未反応の $\mathrm{ZrCl}_{4}$ の一部昇華 (昇華温度 $331^{\circ} \mathrm{C}$ ) が原因と思われる. $300^{\circ} \mathrm{C}$ 以上ではボート中の生成物中には $\mathrm{ZrCl}_{4}$ の回折線 は見られなかった． $400^{\circ} \mathrm{C}$ 以上でほぼ一定の約 $75 \%$ と なった。 なお, $800^{\circ} \mathrm{C}$ 以下では窒化反応よりも還元反応 が優先して起こるため, 窒化反応による重量増加はほと んビ認められなかった. また，図 3 から明らかなように， 窒化反応は $1000^{\circ} \mathrm{C}$ 以上で著しく起こる。したがって, $400^{\circ} \sim 1000^{\circ} \mathrm{C}$ の温度領域では重量変化がほぼ一定とな る.

生成物の経時変化を調べるために, $1000^{\circ} \mathrm{C}, 5 \sim 240$ $\min$ の反応を行い, 生成物をケイ素内部標準の X 線回 折試験で定量した結果を図 5 に示す. 反応初期において 既に塩化物は存在せず, $\mathrm{Al}_{3} \mathrm{Zr}$ が生成した. 時間の経過 に伴い $\mathrm{Al}_{3} \mathrm{Zr}$ は減少し $\mathrm{ZrN}$ の生成量が増大した. $\mathrm{ZrN}$ は $30 \mathrm{~min}$ までの比較的短時間のうちに急激な生成量の 増加を示した.これと並行して重量減少率の変化を調べ たところ, 反応開始後 $5 \mathrm{~min}$ でほぼ一定值に達しており, 白煙の発生も観測されないことからこの温度では反応が 短時間で終了することが分る. 5 min でほぼ一定值に達 するのは，この時点で $\mathrm{ZrN}$ は $50 \%$ 程度生成しており， また, 反応の進行に伴い試料の $\mathrm{Al}$ 及び $\mathrm{Zr}$ 塩化物の蒸 発が起こり $\mathrm{Zr}$ の窒化による重量増とほぼバランスがと れたためと思われる. したがって, 見掛け上, 重量の変 化がない。

そこで, $\mathrm{ZrN}$ の生成速度を検討するために, $850^{\circ}$ $1050^{\circ} \mathrm{C}$ の範囲で $50^{\circ} \mathrm{C}$ 間隔に $\mathrm{ZrN}$ 生成量の経時変化を 調べた. 生成物をX 線回折試験で定量した結果を図 6 に示す. 各温度とも反応開始後 $10 \sim 20 \mathrm{~min}$ で $\mathrm{ZrN}$ 生成 量がほぼ一定量に達しており, 窒化反応が短時間に進行 することが分った。 また, $\mathrm{ZrN}$ 生成量は $950^{\circ} \mathrm{C}$ 以上で 急増しており, 反応温度が窒化物の生成に大きな影響を 与えることが示唆される.

この結果をもとに, 窒化反応の見掛けの活性化エネル 


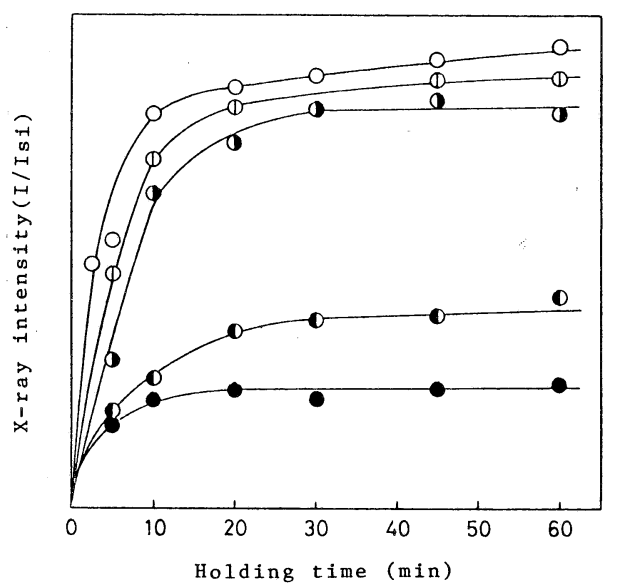

Fig.6. Changes in relative intensity of $\mathrm{X}$-ray diffraction line for $\mathrm{ZrN}$ obtained by heating the powder mixture of $\mathrm{ZrCl}_{4}$ and $\mathrm{Al}(3: 4)$ in $\mathrm{N}_{2}$. Reaction temperature : $850^{\circ} \mathrm{C}, 0900^{\circ} \mathrm{C}, 950^{\circ} \mathrm{C}$, (D) $1000^{\circ} \mathrm{C}, \bigcirc 1050^{\circ} \mathrm{C}$

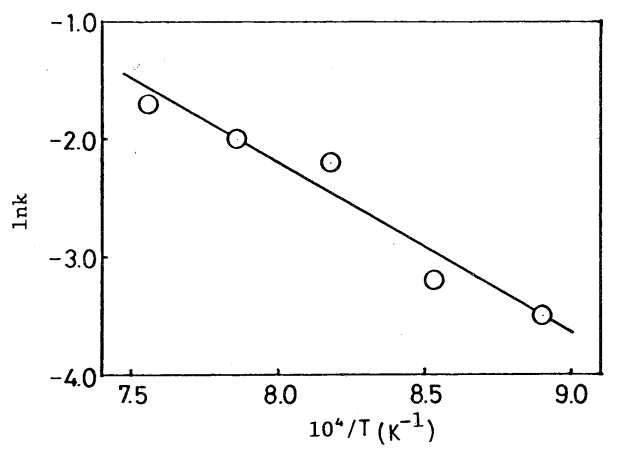

Fig. 7. Arrhenius plot for the system of $\mathrm{ZrCl}_{4}-\mathrm{Al}-\mathrm{N}_{2}$. ギーを算出した. 反応の初期段階を 1 次反応亡仮定し, $1050^{\circ} \mathrm{C}, 1 \mathrm{~h} \sigma \mathrm{ZrN}$ 生成量を基準とし, $\mathrm{ZrN}$ 生成量の 比から反応率を求め, 各温度で速度定数 $k$ を決定し, Arrhenius プロットを行った。図7にその結果を示す. こう配から見掛けの活性化エネルギーは約 28.7 $\mathrm{kcal} / \mathrm{mol}$ となった. $\mathrm{Zr}$ の窒化反応における活性化エネ ルギーについては，幾つかの報告があるが，若尾らは， 昇温法により $860^{\circ} \sim 980^{\circ} \mathrm{C}$ の温度範囲で市販 $\mathrm{Zr}$ 粉末の 窒化では $44.2 \mathrm{kcal} / \mathrm{mol}$, 脱水素 $\mathrm{Zr}$ 粉末の窒化では $40.4 \mathrm{kcal} / \mathrm{mol}$ と報告している ${ }^{19)}$. 単純には比較できな いが，本実験の結果はこれらを下回っており反応が容易 に起こることを示唆している.

$\mathrm{ZrCl}_{4}-\mathrm{Al}-\mathrm{N}_{2}$ 系では生成物が $\mathrm{Al}_{3} \mathrm{Zr}$ から $\mathrm{ZrN}$ へ移行 する過程がみられた。 $\mathrm{Al}_{3} \mathrm{Zr}$ は未反応の $\mathrm{Al}$ が残留した 結果生成したと考えられるので, $\mathrm{Al}_{3} \mathrm{Zr}$ が $\mathrm{ZrN}$ の生成 に与える影響を検討した. まず，流通ガスをアルゴンと し, $200^{\circ} \sim 1100^{\circ} \mathrm{C}$ の温度範囲で $1 \mathrm{~h}$ 反応させた生成物 のX 線回折試験による定量結果を図 8 に示す. $\mathrm{Al}_{3} \mathrm{Zr}$ の 生成は $500^{\circ} \mathrm{C}$ から始まり, $900^{\circ} \mathrm{C}$ で最大量となった。

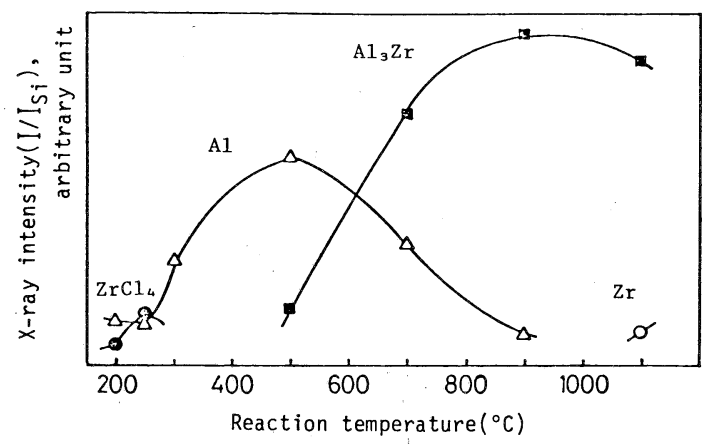

Fig. 8. Changes in relative intensity of X-ray diffraction lines for the products obtained by heating the powder mixture of $\mathrm{ZrCl}_{4}$ and $\mathrm{Al}(3: 4$, molar ratio) in Ar.

Holding time $: 1 \mathrm{~h}$

また， $\mathrm{Al}$ は $900^{\circ} \mathrm{C}$ まで確認され， $1100^{\circ} \mathrm{C} て ゙ ~ Z r$ がわず かに見られた。この結果, 窒化が進まなければ高温でも $\mathrm{Al}_{3} \mathrm{Zr}$ が残留することが分った.

そこで, $\mathrm{Al}$ と $\mathrm{Zr}$ (和光純薬工業製， $97 \%$ 以上粒度 200 メッシュ以下) のモル混合比が $\mathrm{Zr}: \mathrm{Al}=1: 1,1$ : 2 及び $1: 3$ の粉末混合物を調製し, $\mathrm{N}_{2}$ ガス流通下で 1 $\mathrm{h}$ 加熱し，生成物を X 線回折試験で調べた。 Al-Zr 合金 の生成は, $\mathrm{Al}$ の融点 $\left(660^{\circ} \mathrm{C}\right)$ 以上で見られたが，1:3 の試料を用いると $\mathrm{Al}_{3} \mathrm{Zr}$ のみが生成するのに対し， $1: 2$ 及び $1: 1$ の試料では $700^{\circ} \mathrm{C}$ で $\mathrm{Al}_{3} \mathrm{Zr}_{2}, \mathrm{Al}_{2} \mathrm{Zr}$ の合金相 が見られた. $1000^{\circ} \mathrm{C}$ 以上では，各試料とも $\mathrm{ZrN}$ が生成 したが，生成量は $\mathrm{Al}$ の割合が少ない試料ほど多かった。 図 9 にX 線回折線の一例を示す. $1: 3$ の試料は $1050^{\circ} \mathrm{C}$ で加熱しても $\mathrm{Al}_{3} \mathrm{Zr}$ 量が多いことが分る. また, $1: 2$ の $1000^{\circ} \mathrm{C}$ では $\mathrm{Al}_{2} \mathrm{Zr}$ の回折線がわずかに見られたが， 保持時間を長くすると見られなくなった。 $\mathrm{Al}_{3} \mathrm{Zr}$ の融点 は $1580^{\circ} \mathrm{C}$ と高く ${ }^{20)}$, 安定な合金相であり, $1000^{\circ} \mathrm{C}$ 程度 の反応温度では, $\mathrm{Zr}$ を離脱させ $\mathrm{ZrN}$ を生成することは 容易ではないと考えられる。また，塩化物は反応初期で ほとんど見られなくなり, 竹之内らが $\mathrm{TiCl}_{3}-\mathrm{Al}-\mathrm{N}_{2}$ 系 から $\mathrm{TiN}$ の生成の際に提案した合金からの“引き抜き 反応” ${ }^{10)}$ が起こる可能性もない。むしろ, 反応中は，生 成した $\mathrm{Zr}$ と残留 $\mathrm{Al}$ が共存しても直ちに安定な $\mathrm{Al}_{3} \mathrm{Zr}$ 相とならず， N と Z r が反応できる状態にあるが，窒化 が進まない場合は, 結果的に $\mathrm{Al}_{3} \mathrm{Zr}$ が生成すると考えら れる.このことは，アルゴンガス流通下で反応を行い, 更に，流通ガスを窒素に換えて得られた生成物では，同 じ温度で窒化のみを行った場合よりも $\mathrm{Al}_{3} \mathrm{Zr}$ 量が多くな ることからも分る. また，時間の経過に伴い $\mathrm{Al}_{3} \mathrm{Zr}$ 量が 減少するのは未反応の $\mathrm{Zr}$ 塩化物と反応して $\mathrm{AlCl}_{3}$ を生 成し, 分離した $\mathrm{Zr}$ が $\mathrm{N}$ と反応するためと思われる.

ここで, 以上の結果をもとに反応過程をまとめると, $300^{\circ} \mathrm{C}$ 付近で還元が始まり, $\mathrm{ZrCl}_{3}$ が生成する。ただし, $\mathrm{ZrCl}_{4}$ の昇華量が多く, $\mathrm{ZrCl}_{3}$ は生成してもわずかであ 

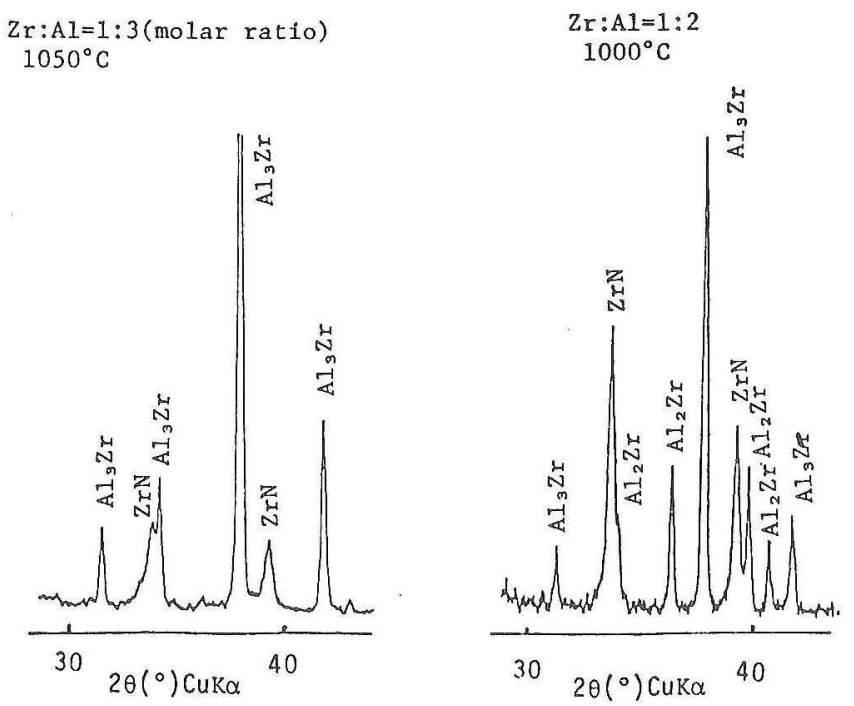

$\mathrm{Zr}: \mathrm{Al}=1: 1$

$1000^{\circ} \mathrm{C}$

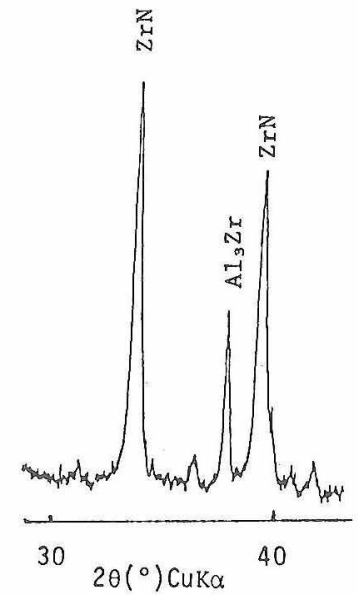

Fig.9. X-ray diffraction patterns of the products obtained by heating the powder mixture of $\mathrm{Zr}$ and $\mathrm{Al}$ in $\mathrm{N}_{2}$.

Holding time $: 1 \mathrm{~h}$

る。また, $\mathrm{ZrCl}_{3}$ は分解に際して, 不均化反応により $\mathrm{ZrCl}_{4}$ と $\mathrm{ZrCl}_{2}$ になると思われるが，分解温度が $350^{\circ} \mathrm{C}$ と低いため, 生成しても生成物中に残らない可能性があ る。たとえ残留したとしてもX線で十分同定できるほ ビの量は存在しない。

$300^{\circ} \mathrm{C} \sim: \mathrm{ZrCl}_{4}(\mathrm{~s})+1 / 3 \mathrm{Al}(\mathrm{s}) \rightarrow \mathrm{ZrCl}_{3}(\mathrm{~s})$

$$
+1 / 3 \mathrm{AlCl}_{3}(\mathrm{~g})
$$

ここで，（s）は固体，（g）は気体を示す.

$500^{\circ} \mathrm{C}$ 以上では，更に還元が進み，活性な $\mathrm{Zr}$ (以下 $\mathrm{Zr}^{+}$とする) が生成する.

$500^{\circ} \mathrm{C} \sim: \mathrm{ZrCl}_{3}(\mathrm{~s})+\mathrm{Al}(\mathrm{s}) \rightarrow \mathrm{Zr}^{+}(\mathrm{s})+\mathrm{AlCl}_{3}(\mathrm{~g})$ ( 2$)$

$\mathrm{Zr}^{+}$は直ちに $\mathrm{Al}$ あるいは窒素と結合する. $800^{\circ} \mathrm{C}$ か らは Z $\mathrm{rN}$ が生成するが, 窒化が進まない場合には $\mathrm{Al}_{3} \mathrm{Zr}$ となる。

$800^{\circ} \mathrm{C} \sim: \mathrm{Zr}^{+}(\mathrm{s})+1 / 2 \mathrm{~N}_{2}(\mathrm{~g}) \rightarrow \mathrm{ZrN}(\mathrm{s})$

$500^{\circ} \sim 1000^{\circ} \mathrm{C}: \mathrm{Zr}^{+}(\mathrm{s})+3 \mathrm{Al}(\mathrm{s}, 1) \rightarrow \mathrm{Al}_{3} \mathrm{Zr}(\mathrm{s})$

ここで，(1)は液体を示す.

図 10 に， $1950^{\circ} \mathrm{C} ， 1 \mathrm{~h}$ 反応で得られた粉末の走查型 電子顕微鏡写真を示す。 $0.1 \sim 0.3 \mu \mathrm{m}$ 程度の粒子が凝集 している様子が観察される。この生成物の $\mathrm{ZrN}$ 相の格 子定数 $a$ は $4.575 \AA$ で文献值 $4.577 \AA$ に近いことから, ほほ量論組成比に近いものが得られたことが分る。また， $\mathrm{ZrN}$ の結晶子径の平均值は $259 \AA$ ，比表面積は 22.7 $\mathrm{m}^{2} / \mathrm{g}$ であった。

生成物中には，わずかの $\mathrm{Al}$ が残留することもあるが， 試料を加圧成形し，原料粉末間の接触を改善すれば，反 応率が向上し，残留 $\mathrm{Al}$ は減少するものと思われる，Al が残留した生成物を常温で $1 \mathrm{~N}$ 水酸化ナトリウム溶液 中に放置したのち，蒸留水及びアセトンで洗浄したとこ

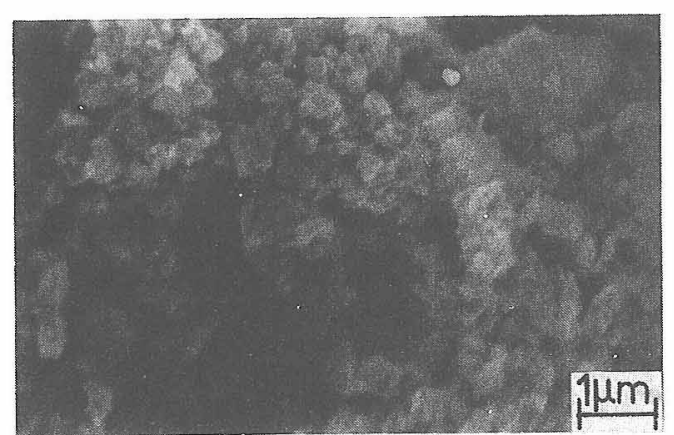

Fig. 10. Scanning electron micrograph of the product obtained by heating the powder mixture of $\mathrm{ZrCl}_{4}$ and Al ( $3: 4$, molar ratio) in $\mathrm{N}_{2} \cdot 1050^{\circ} \mathrm{C}, 1 \mathrm{~h}$

ろほぼ未反応の $\mathrm{Al}$ が除去できることが分った。しかし， わずかに残留する $\mathrm{Al}_{3} \mathrm{Zr}$ は水酸化ナトリウム処理では除 去することはできなかった。

\section{$3.2 \mathbb{Z} \mathrm{rN}$ の合成に及ぼす $\mathrm{Mg}$ 及び $\mathbb{Z n}$ の影響}

$\mathrm{Mg}$ は還元力が強く，金属ジルコニウムの製造法とし ては $\mathrm{ZrCl}_{4}$ を $\mathrm{Mg}$ で還元する方法 ${ }^{211}$ が一般的である。し かし，副生物の塩化マグネシウム（II）の沸点が $1418^{\circ} \mathrm{C}$ 亡高く，生成物中に残留して反応を中断してし まうため22!，八ロゲン化物法で $\mathrm{Mg}$ を用いた報告はない。

図 11 に, $\mathrm{ZrCl}_{4}-\mathrm{Mg}-\mathrm{N}_{2}$ 系, $1000^{\circ} \mathrm{C}, 1 \mathrm{~h}$ 反応の生成 物のX線回折図の一例を示す。合金相は見られないが, Z r の回折線が見られ，窒化が十分に進んでいないこと

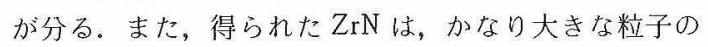
集合体であった。

一方，Znは還元力はあまり強くないが，副生物の塩 化亜鉛（II）が $730^{\circ} \mathrm{C}$ で気化する。 $\mathrm{Zn}$ 自身も沸点が 


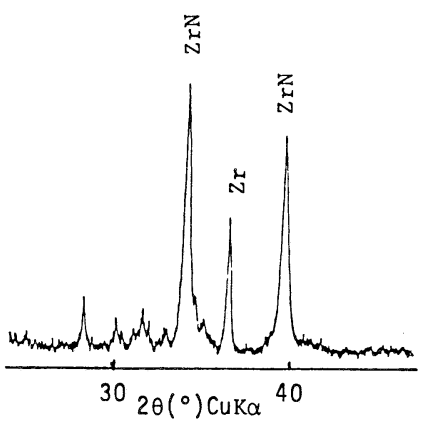

Fig. 11. X-ray diffraction pattern of the product obtained by heating the powder mixture of $\mathrm{ZrCl}_{4}$ and $\mathrm{Mg}\left(1: 2\right.$, molar ratio) in $\mathrm{N}_{2}$.

Holding time $: 1 \mathrm{~h}$

$930^{\circ} \mathrm{C}$ であることから純度の高い目的物質を得ることが 期待できる．八ロゲン化物法でも，炭化二オブの合成 ${ }^{23)}$ で有効であった。しかし， $\mathrm{ZrCl}_{4}-\mathrm{Zn}-\mathrm{N}_{2}$ 系では $\mathrm{ZrN}$ を 得ることができなかった。これは，Zn の還元力は沸点 以下ではほとんど発揮されず， $\mathrm{ZrCl}_{4}$ の昇華のみが起 こったためであると考えられる.

\section{4. 結言}

本研究では, 還元剤に $\mathrm{Al}, \mathrm{Mg}$ 及び $\mathrm{Zn}$ の粉末を用い, 窒素ガス流通下で $\mathrm{ZrCl}_{4}$ からの $\mathrm{ZrN}$ の合成を試みた。 まず， $\mathrm{ZrCl}_{4}-\mathrm{Al}-\mathrm{N}_{2}$ 系では次のような過程で反応が進行 することが分った.

$$
\begin{gathered}
300^{\circ} \mathrm{C} \sim \quad \mathrm{ZrCl}_{4}(\mathrm{~s})+1 / 3 \mathrm{Al}(\mathrm{s}) \rightarrow \mathrm{ZrCl}_{3}(\mathrm{~s}) \\
+1 / 3 \mathrm{AlCl}_{3}(\mathrm{~g})
\end{gathered}
$$

$\mathrm{ZrN}$ の生成は $800^{\circ} \mathrm{C}$ より開始するが, $\mathrm{ZrCl}_{4}$ の昇華損 失が大きく, $\mathrm{Al}$ の残留も認められた。この $\mathrm{Al}$ の残留に より，窒化が進まない場合， $\mathrm{Al}_{3} \mathrm{Zr}$ が生成することが明 らかとなった.この窒化反応の見掛けの活性化エネル ギーは約 $28.7 \mathrm{kcal} / \mathrm{mol}\left(850^{\circ} \sim 1050^{\circ} \mathrm{C}\right)$ であった。 $1050^{\circ} \mathrm{C}, 1 \mathrm{~h}$ 反応で得られた生成物は微粉末で, $\mathrm{ZrN}$ 相 の格子定数 $a$ が $4.575 \AA$, 結晶子径が $259 \AA$ であった.
$\mathrm{Mg}$ 還元では, $\mathrm{Al}$ 還元に比べて窒化の進行が遅く, 粗大粒子よなった。 また， $\mathrm{Zn}$ 還元では $\mathrm{ZrN}$ を得ること はできなかった。

以上のように，3 種類の還元金属の中では, $\mathrm{Al}$ が最 も有効であり, $\mathrm{Al}$ 還元により比較的低温, 短時間で $\mathrm{ZrN}$ の微粉末を合成することができた。

\section{文献}

1) L.E. Toth, "Transition Metal Carbides and Nitrides". Academic press, New York and London (1971) p. $4-28$.

2) C. Agte and K. Moers, Z. Anorg. Allg. Chem., 198, 233-75 (1931).

3) I. Campbell, C. Powell, D. Nowicki and B. Gonser, J. Electrochem. Soc., 96, 318-33 (1949).

4）高橋武彦, 伊藤秀章, 野口章一郎, 日化, 1975, 627-31.

5）三好正信, 玉利信幸，加藤昭夫，日化，1978，822-26。

6) R. Juza, A. Gabel, H. Rabenau and W. Klose, Z. Anorg. Allg. Chem., 329, 136-45 (1964).

7) 三田村 孝，セラミックス，17，556-61 (1982).

8) T. Mitamura, M. Kanno and T. Mukaibo, J. Nucl. Sci. Technol., 5, 60-64 (1968).

9）森 忠芸, 川上 登, 竹之内雅典, 三田村 孝, 電化, 47, 355-59 (1979).

10）竹之内雅典, 森 忠芸, 飯田武揚, 三田村 孝, 日化, 1979, 861-68.

11）森 忠芸, 大石佳孝, 川上 登, 三田村 孝, 松田常雄, 電化，45，489-90 (1977).

12) D.R. Stull, H. Prophet, "JANAF Thermochemical Table", Second edition, Nat. Bur. Stand., U.S. (1971).

13) O. Kubaschewski and E. LL. Evans, "Metallurgical Thermochemistry”, Pergamon Press Ltd. (1958).

14）日本化学会編, 実験化学講座, 第 4 巻, “固体物理学”, 丸善 (1956) p. 244 .

15）慶伊富長, “吸着”, 共立出版（1965）p. 105.

16) T. Mitamura, T. Mori and M. Kikuchi, Denki Kagaku, 44, 704-08 (1976).

17）森 忠芸, 川上 登, 神谷純生, 三田村 孝, 電化, 45, 454-56 (1977).

18）森 忠芸, 川上 登, 月館隆明, 三田村 孝, 電化, 47 , 225-28 (1979).

19）若尾慎二郎, 渡辺恒美, 工化，72，2202-10 (1969).

20) G. V. Kidson and G. D. Miller, J. Nucl. Mater., 12, 61-69 (1964).

21）石塚 博, 公開特許公報, 50-109108.

22) F. Gorle, H. Ooms and M. Brabers, Am.' Ceram. Soc. Bull., 53, 237-42 (1974).

23）荒川敏彦, 神山美英, 森 忠芸, 飯田武揚, 三田村 孝, 電化，50，357-58 (1982). 